\title{
IDENTIFICATION OF SUITABLE AREAS FOR IRRIGATED RICE CROPPING USING MODIS IMAGES AND HAND MODEL
}

Doi:http://dx.doi.org/10.1590/1809-4430-Eng.Agric.v36n2p 329-341/2016

\section{VAGNER P. MENGUE ${ }^{1}$, DENISE C. FONTANA ${ }^{2}$}

\begin{abstract}
One of the most relevant activities of Brazilian economy is agriculture. Among the main crops in Brazil, rice is one of high relevance. The state of Rio Grande do Sul, in Southern Brazil, is responsible for $68.7 \%$ of domestic production (IBGE, 2013). The goal of this study was to develop a low-cost methodology with a regional scope to identify suitable areas for irrigated rice cropping in this state, using spectro-temporal behavior of vegetation index by means of MODIS images and HAND model. The rice-cropped area of this study was the southern half of the State. Using the HAND model, flood areas were mapped to identify irrigated rice cultivation. We used multi-temporal images of vegetation index from MODIS sensor, covering the period from August 2001 to May 2012. To assess the results, we used data collected in the fields and cropped area information from IBGE. The results showed that the proposed methodology was satisfactory, with Kappa 0.92 and global accuracy of $98.18 \%$. As result, MODIS sensor data and flood areas delineation by means of HAND model generated the estimate irrigated rice area for the area of study.
\end{abstract}

KEYWORDS: HAND Model, EVI, MODIS, irrigated rice, mapping.

\section{DISCRIMINAÇÃO DE ÁREAS UTILIZÁ VEIS PARA CULTIVO DE ARROZIRRIGADO UTILIZANDO IMAGENS MÓDIS E O MODELO HAND}

RESUMO: Uma das atividades mais relevantes para a economia brasileira é a agricultura. $\mathrm{O}$ arroz está entre os produtos de maior importância no cenário agrícola nacional, e o Estado do Rio Grande do Sul é o responsável por 68,7 \% da produção nacional (IBGE, 2013). O objetivo deste trabalho foi desenvolver uma metodologia de baixo custo, com uma abrangência regional capaz de discriminar as áreas utilizáveis para o cultivo de arroz irrigado, no Estado do Rio Grande do Sul, a partir do comportamento espectro-temporal de índices de vegetação de imagens MÓDIS e do Modelo HAND. A área de estudo limitou-se à metade sul do Estado do Rio Grande do Sul, que compreende a região produtora de arroz irrigado, onde, a partir do modelo HAND, foram mapeadas as áreas de inundação para discriminar a cultura do arroz irrigado. Foram utilizadas imagens multitemporais de índice de vegetação EVI do sensor MÓDIS, abrangendo o período de agosto de 2011 a maio de 2012. Para avaliar os resultados, foram utilizados dados coletados a campo e dados de área cultivada do IBGE. Os resultados mostraram que a metodologia proposta foi satisfatória, com Kappa de 0,92 e Exatidão Global de 98,18\%. Portanto, o uso de dados multitemporais e de moderada resolução espacial, provenientes do sensor MÓDIS, aliados à delimitação de áreas próprias para inundação, utilizando o modelo HAND, torna possível gerar e disponibilizar dados de estimativa de área cultivada de arroz irrigado para a área de estudo.

PALAVRAS-CHAVE: Modelo HAND, EVI, MÓDIS, arroz irrigado, mapeamento.

\footnotetext{
${ }^{1}$ Geógrafo, Estudante de Doutorado, Universidade Federal do Rio Grande do Sul (UFRGS), Centro Estadual de Pesquisas em Sensoriamento Remoto e Meteorologia (CEPSRM), Avenida Bento Gonçalves, 7712, 91540-220 - Porto Alegre-RS, vagnergeo@yahoo.com.br

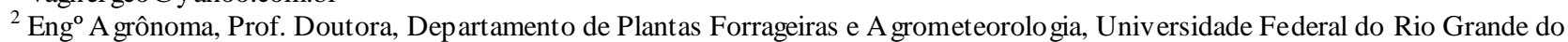
Sul (UFRGS) - Avenida Bento Gonçalves, 7712, 91540-220 - Porto Alegre - RS, dfontana@ufrgs.br 


\section{INTRODUCTION}

One of the main activities of Brazilian economy is agriculture. This is a sector with high potential for growth and critical to the balance of trade. In 2012, the agribusiness sector was responsible for approximately U\$95.81 billion in foreign exchange revenue. This represented 39.5\% of total Brazilian sales abroad (MAPA, 2012). It is important that the country invest in modernization and qualification of applicable technologies in monitoring systems, estimates and crop forecasting. Objective and accurate methods can improve agricultural policies related to inventory control and marketing. Several studies point out MODIS sensor images (Moderate Resolution Imaging Spectroradiometer) as a tool of mapping development. They are based on the spectro-temporal attributes of crops (HERMANCE et al,2007; EPIPHANIO et al., 2010; VICTORIA et al., 2012; RISSO et al., 2012; JOHANN et al., 2012; BROWN et al., 2013). The spectral variations are used as criterion to differentiate growing areas. This is successful when there is compatibility between the spatial resolution of the sensor and the size of crops. As well as when the recommended sowing range is narrow. There is, however, a lack of tests for these methodologies at specific conditions of irrigated rice, because of singularities of the crops in Rio Grande do Sul State.

This State is the largest rice producer in the country. In crop season 2011/2012, the State produced 7.6 million tons, which represented $66.6 \%$ of national production (IBGE, 2013). The production is limited to the southern half of the State, given the geographic characteristics, soil, weather and the land issues. These elements facilitate satellite mapping. The irrigated rice cultivation is preferably carried out in soils that are mostly plain areas or those with a little undulation. These areas occur in lowlands, usually poorly drained, called floodplains (MUNARETO et al., 2010).

In recent years, soybean production has become relevant also in the southern half of the state (SANTOS et al., 2014). Soybean and rice crops have similar phenological cycles. Thus, techniques of remote sensing become complex when using spectro-temporal attributes to differentiate croplands. This brings more error possibilities for mappings (KLERING et al., 2013). Thus, the correct delimitation of wetland areas can be considered as a key issue to improve crop mapping. This allows distinction of irrigated rice areas occupied by other coincident crops cycles, such as soybeans.

The quantitative topographic algorithm, so-called Height above the Nearest Drainage (HAND) (RENNÓ et al, 2008; NOBRE et al., 2011) identifies floodplains and appropriate areas for irrigated rice crops. It is an important tool with relevant characteristics such as low cost and easy implementation.

D'ARCO (2007) performed the correlation method test using altimetry and soil type data to delimit and separate rice-cropped areas from other crops. The author considered the results satisfactory; but the scale of soil map (1:750.000) impaired results for small areas. In addition, there was the omission of several land information. HAND model uses only input data as Digital Elevation Model, providing information of the vertical distance to the nearest drain. Thus, HAND model defines accurate areas for cultivation of irrigated rice, with fast implementation. The scale of analysis will depend on HAND data resolution.

Therefore, the objective of this study was to develop a methodology of regional scope using vegetation index of MODIS sensor and HAND model. In order to identify appropriate areas for irrigated rice crops.

\section{MATERIAL AND METHODS}

The study area covers the southern half of Rio Grande do Sul State, which includes ricecropped areas. This region is located between the geographic coordinates of $28^{\circ} 00^{\prime}$ and $33^{\circ} 45^{\prime}$ south latitude and $49^{\circ} 43^{\prime}$ and $57^{\circ} 39^{\prime}$ west longitude. The area was divided according to politicaladministrative regions of the Instituto Riograndense de Arroz Irrigado - IRGA (Institute of Irrigated 
Rice in Rio Grande do Sul), as follows: western border, prairie, central slope, internal and external plains of the Lagoa dos Patos, and southern zone (Figure 1). The study was conducted from August 2011 to May 2012. It included the rice crop de velopment during the 2012 crop season.

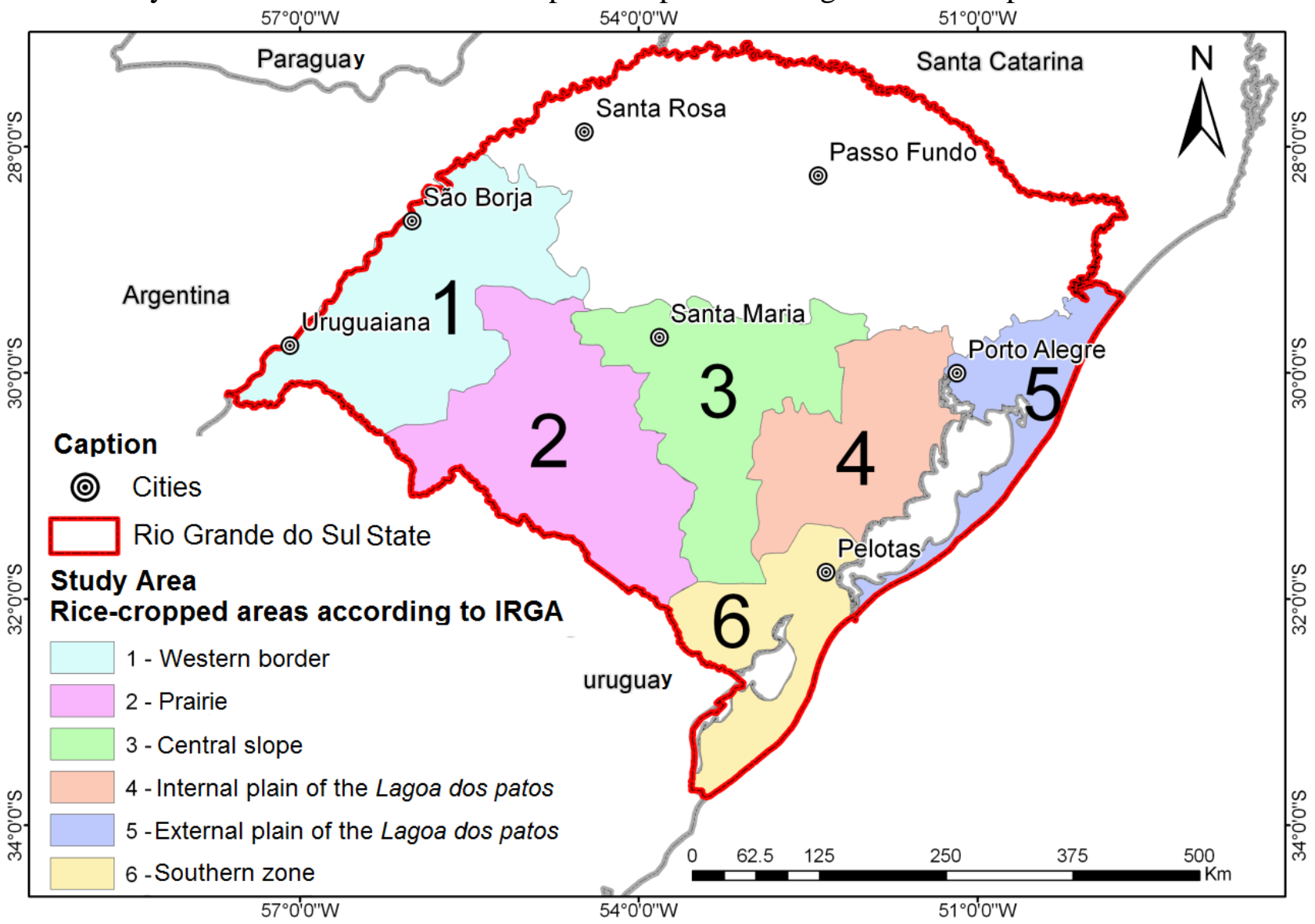

FIGURE 1. Location of the study area.

We used images from TERRA satellite, MODIS sensor, MOD13Q1 product, collection 5. They contain image compositions of 16 days as enhanced vegetation index (EVI), (HUETE et al., 1994) with a spatial resolution of $250 \mathrm{~m}$. This product was obtained free of charge at Embrapa site (BRASIL, 2014).

The flat bottom smoother filter was applied to smooth the temporal spectrum curve. The filter was also used to reduce noises caused by clouds, detector failures, viewing geometry, among others (WARDLOW et al, 2006). For this, we used the programming language called Interactive Data Language (IDL), 7.1.2 version, adapted by EMBRAPA Agricultural Informatics.

The irrigated rice masks were built through images of minimum and maximum EVI rate (Enhanced Vegetation Index). The images were obtained from the spectro-temporal periods with high and low vegetation index for each crop. The spectro-temporal profile was drawn from EVI standard assessment of pixels classified as irrigated rice in the reference map. The map was built using RapidEye sensor images of 01/10/2012 and 02/14/2012. Images were obtained through the EMBRAPA project Metodologia para Mapeamento da Agricultura Brasileira (Methodology for Brazilian Agriculture Mapping). They have resolution of $5 \mathrm{~m}$ and each scene is an area around 628 $\mathrm{km}^{2}$.

To establish the minimum EVI image, we used five images of 09/14/2011 and 11/17/2011. They contemplated the pre-planting and initial development of the culture. The period from 11/17/2011 to 04/22/2012 was used to generate the image of maximum EVI with 11 images (Figure 2). The established periods aimed to compose minimum and maximum EVI images of crops in different management conditions. Especially sowing time and type of cycle. 


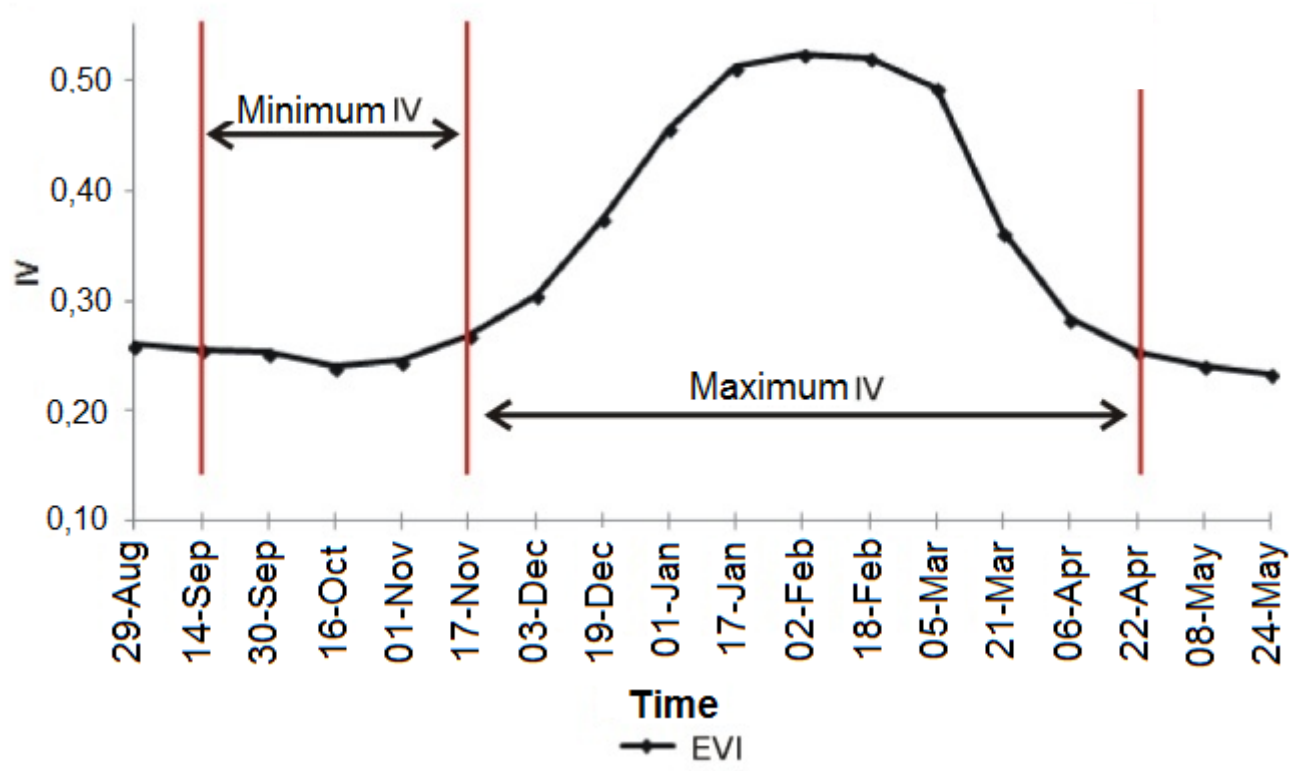

FIGURE 2. Average spectro-temporal profile of irrigated rice in Rio Grande do Sul; minimum and maximum EVI periods are marked over the cycle.

Several tests with different classifier algorithms were made. The method of supervised parallelepiped classification obtained the best results for generation of crop mask of irrigated rice crops. Samples for classifier training were collected in RGB colored image. This was used only to highlight cultivated areas with spring and summer crops. To design the colored composition, the maximum image was placed in channel $\mathrm{R}$ (red). The image of the minimum was placed in channels $\mathrm{G}$ (green) and B (blue). The red areas represent summer crops and the other colors represent other targets.

For implementation, we used data from SRTM (Shuttle Radar Topographic Mission), which were obtained with no charges from the Embrapa website (BRASIL, 2005). The SRTM images were obtained with compatible scale 1:250.000 (BRASIL, 2012). It took 21 images to compose the mosaic that covers the entire study area. The study was developed on ENVI 4.7 software (EXELIS VISUAL INFORMATION SOLUTIONS, 2010). Distributed Hydrologic Modeling System was used to process SRTM data and generate HAND model. This system is also called TerraHidro and is inside TerraView software, developed by Instituto Nacional de Imagens Espaciais (National Institute for Space Research) (INPE, 2010).

TerraView Software began processing with interpolation of some flaws, also called sinks of SRTM topographic data. Next processing step was generation of flow direction (Local Drain Direction - $L D D)$. Also, accumulated drainage areas that are generated from LDD. By creating these two inputs (flow direction and accumulated areas), automatic delineation of drainage network was generated. Using these two inputs, the last step of the process was performed: the creation of HAND model.

The HAND image was exported in GeoTIFF format and it was sliced in order to define flood area. This means that flooding level was chosen from the nearest drainage. Height value was not the same for all rice crop areas. Minimum height was $8 \mathrm{~m}$ and in some areas, the maximum height was $40 \mathrm{~m}$. Wetland areas were identified by means of satellite images to choose the height. These satellite images with better spatial resolution were Landsat 5 TM (30 m spatial resolution) and Resource Sat-1 (24 m spatial resolution). After the slicing, a 5x5 yard median convolution filter was applied to eliminate small inconsistencies. These were holes caused by local topography inside flood area (Figure 3). Finally, resampling of HAND model from $90 \mathrm{~m}$ to $250 \mathrm{~m}$ were made in order to check compatibility with MODIS images. 


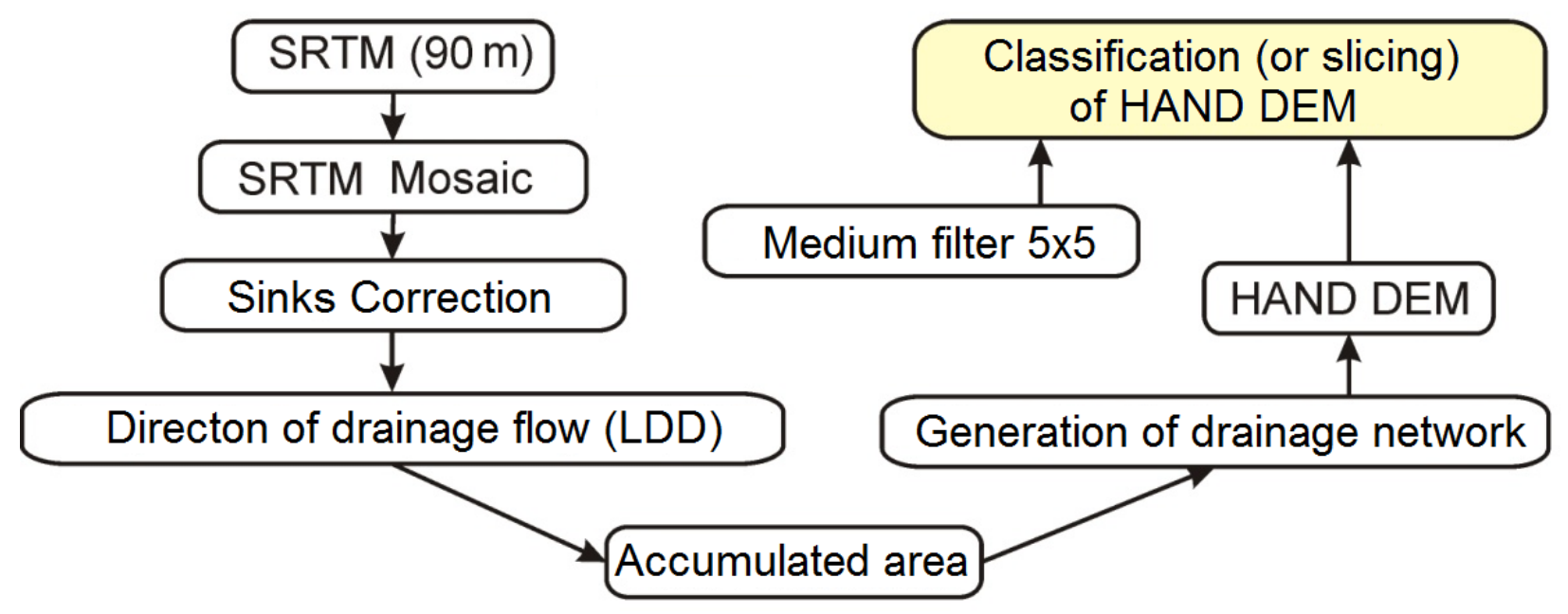

FIGURE 3. Diagram illustrating steps of HAND model generation.

The last step was flood area crossings with irrigated rice classifications, which were obtained through the HAND model. Such methodological procedure aims to identify appropriate areas for irrigated rice crops. This is made by separating areas of other crops with similar phenological cycles. In the state, floodplains are mostly used for rice crops. They are found in plains close to rivers and lakes. HAND land descriptor was used to identify them.

Data from growing area (ha) of irrigated rice crops were used as reference. Those were obtained through Systematic Survey of Agricultural Production (LSPA), elaborated by IBGE on $2011 / 2012$ season in the state.

A field survey in the study area was conducted from 19 to 22 April 2012. This was made in order to assess the quality of results obtained through process of images classification and interpretation. During four days of field survey, a GPS receptor collected 2,596 points of land use. They were distributed over a course of approximately $1,700 \mathrm{~km}$. By using these field data, we calculated the kappa index (KI). Also overall accuracy (OA) on classification of MODIS sensor multitemporal data. In the analysis were computed only representative field points for mapping scale of MODIS sensor. This means that areas considered small (less than 40 hectares) were omitted from the validation analysis.

\section{RESULTS AND DISCUSSION}

The flood area generated by HAND model occupies 9,423,250 hectares. This represents about $56.9 \%$ of the area that produces irrigated rice in the state (Figure 4). Therefore, much of the southern half of Rio Grande do Sul has appropriate conditions for growing rice. This area has a slightly undulating terrain. It has appropriate conditions for growing rice and water for irrigation is feasible.

Only part of the flood area is effectively used for rice cultivation. KLERING et al. (2013) mapped a potential area for rice crops of 3,322,037 ha. They used a series of 10 harvests and MODIS images. However, according to SOSBAI (2012), areas of irrigated rice cover about 5.4 million hectares of lowlands. Of these, around three million hectares are used for irrigated rice, which is annually grown just over one million hectares. It can be explained by the adoption of fallow system and crop rotation, which is in average two years. 


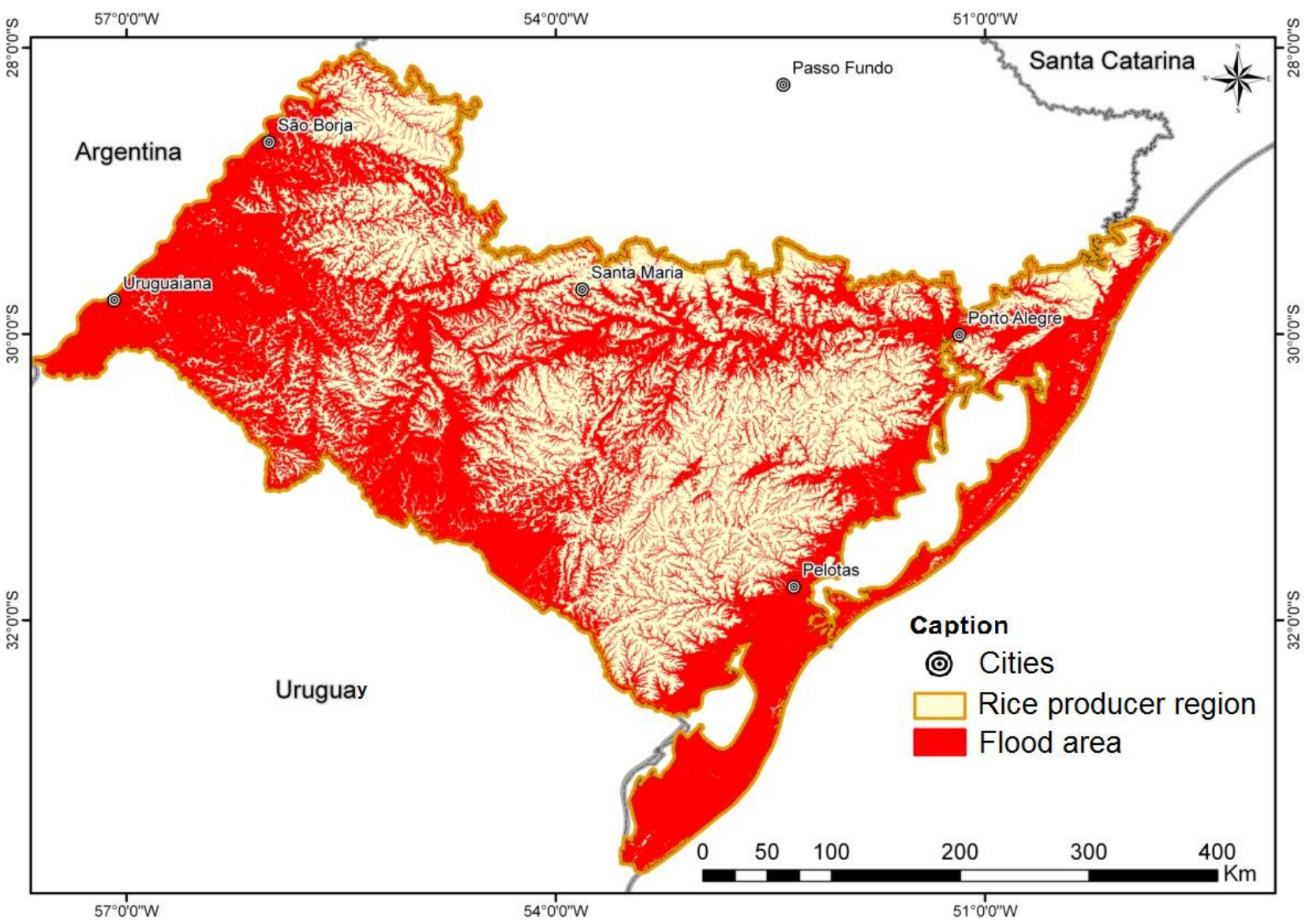

FIGURE 4. Flood area location generated by HAND model with minimum height of $8 \mathrm{~m}$ to $40 \mathrm{~m}$ from the nearest drain.

Regarding the flood mask, a 5x5 yard median convolution filter was applied. The visual analysis shows that the filter eliminated small holes caused by local topography. This was made without significantly altering the shape of flood area, making it more uniform and homogeneous (Figure 5).
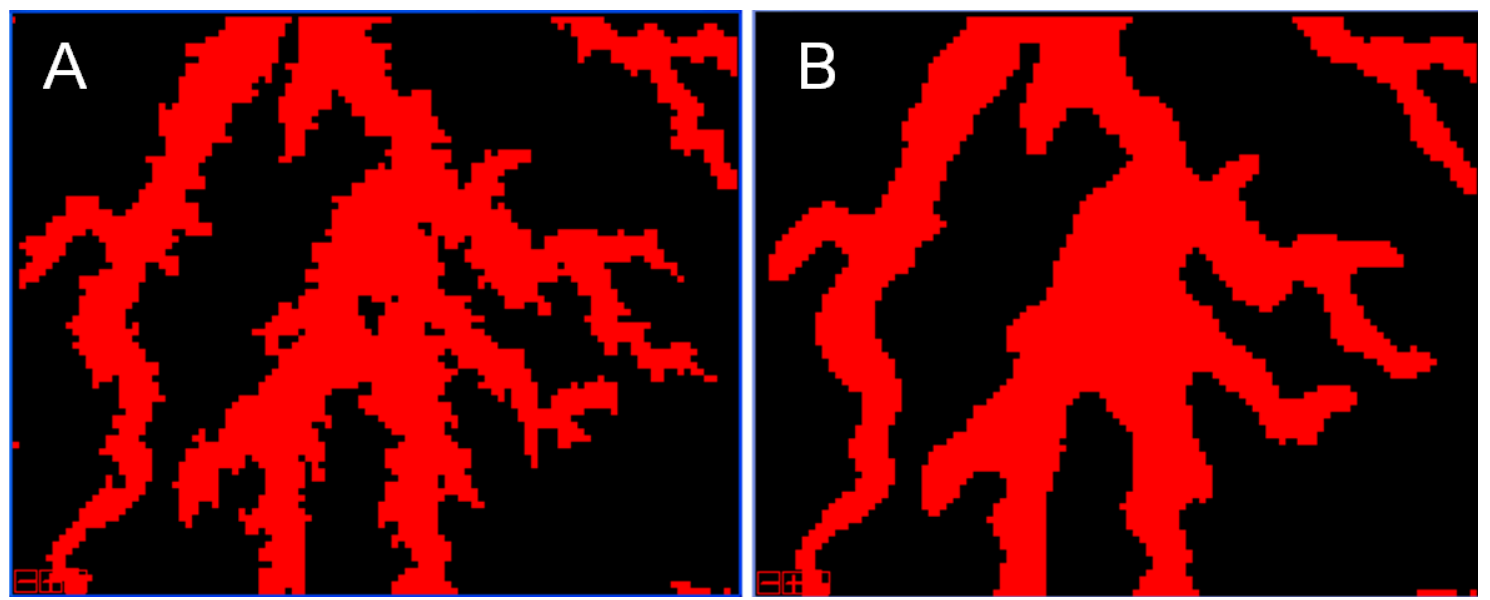

FIGURE 5. Application exemple of the $5 \times 5$ median filter in flood area. Sample (A) without filter and sample (B) with filter application.

The area classified as rice cultivation crosses flood area (based on spectro-temporal attribute of MODIS images). This creates $1,215,528$ ha of rice cultivation total area. The generated data was $16.59 \%$, higher than official one, 1,042,560 ha (IBGE, 2013). Despite that, considering MODIS sensor resolution, this is satisfactory. Also because of systematic classification, fast processing and estimation of regional scope. 
Analysis of rice crops (Figure 6) shows the importance of using flood area. In all regions, estimates of cultivation area with flood mask were closer to reference data (IBGE) than without its application. The highest average deviations occurred in the largest cultivation areas of the State, such as prairie, southern zone, central slope and western border. The smallest deviations occurred in external and internal plain. D'ARCO (2007) also found the largest overestimates in cities located in regions with larger cultivations. It differs, however, from the results of KLERING et al. (2013). They found that the smallest errors were in the largest cultivated area of the State. It is important to point out that some errors found may be related to reference data that was used. Because this information may contain uncertainties inside the methodology used by IBGE. Analyzing IBGE estimates, there is a conservative trend regarding expansion and reduction of irrigated rice crops, in recent years in the state. D' ARCO (2007) and KLERING et al. (2013) pointed out that vegetation data indices are less conservative. They had more variation of cultivation area over the same period. This shows that official estimates have a little sensitivity to local variations generated by weather and economy. This characteristic may influence directly estimates of certain areas of the state.

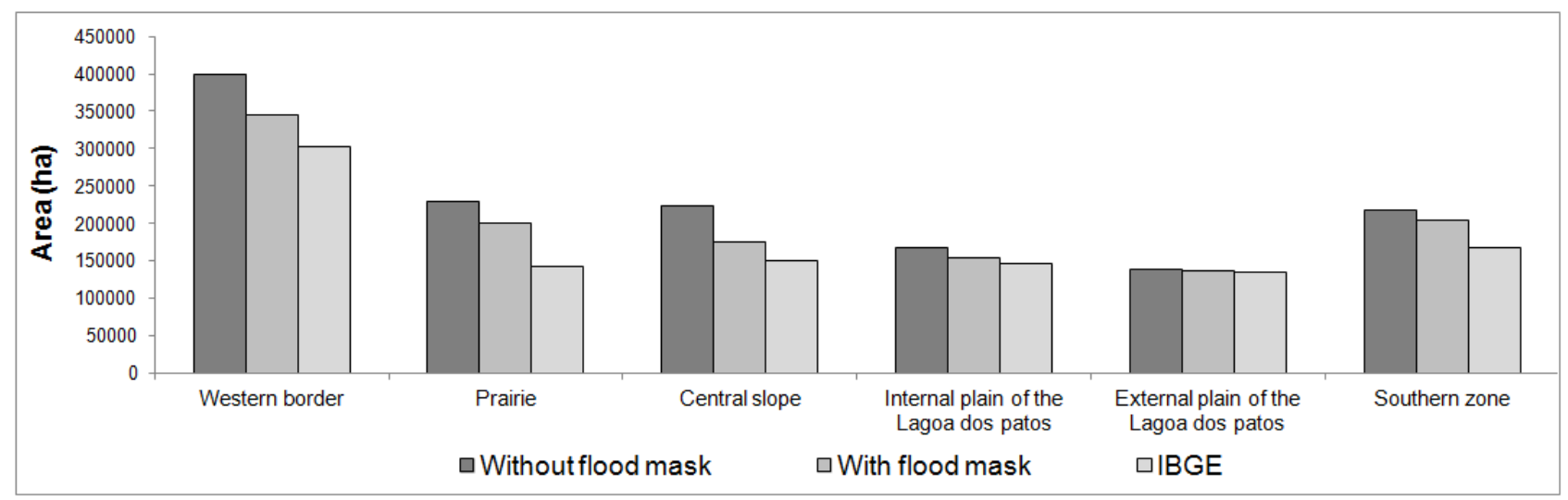

FIGURE 6. Calculation of cultivation areas with and without flood mask for rice crop areas in the state of Rio Grande do Sul.

EVI images allow quantification of areas of the state, region or city. It also creates the spatial location (mapping) of crops. This information is very useful for monitoring systems, or even for agricultural insurance sector, dynamic studies of cultivation, among others. The crops are located near waterbodies (rivers, ponds, lakes...). As expected, they occupied only a small part of the appropriate area for cultivation (Figure 7). 


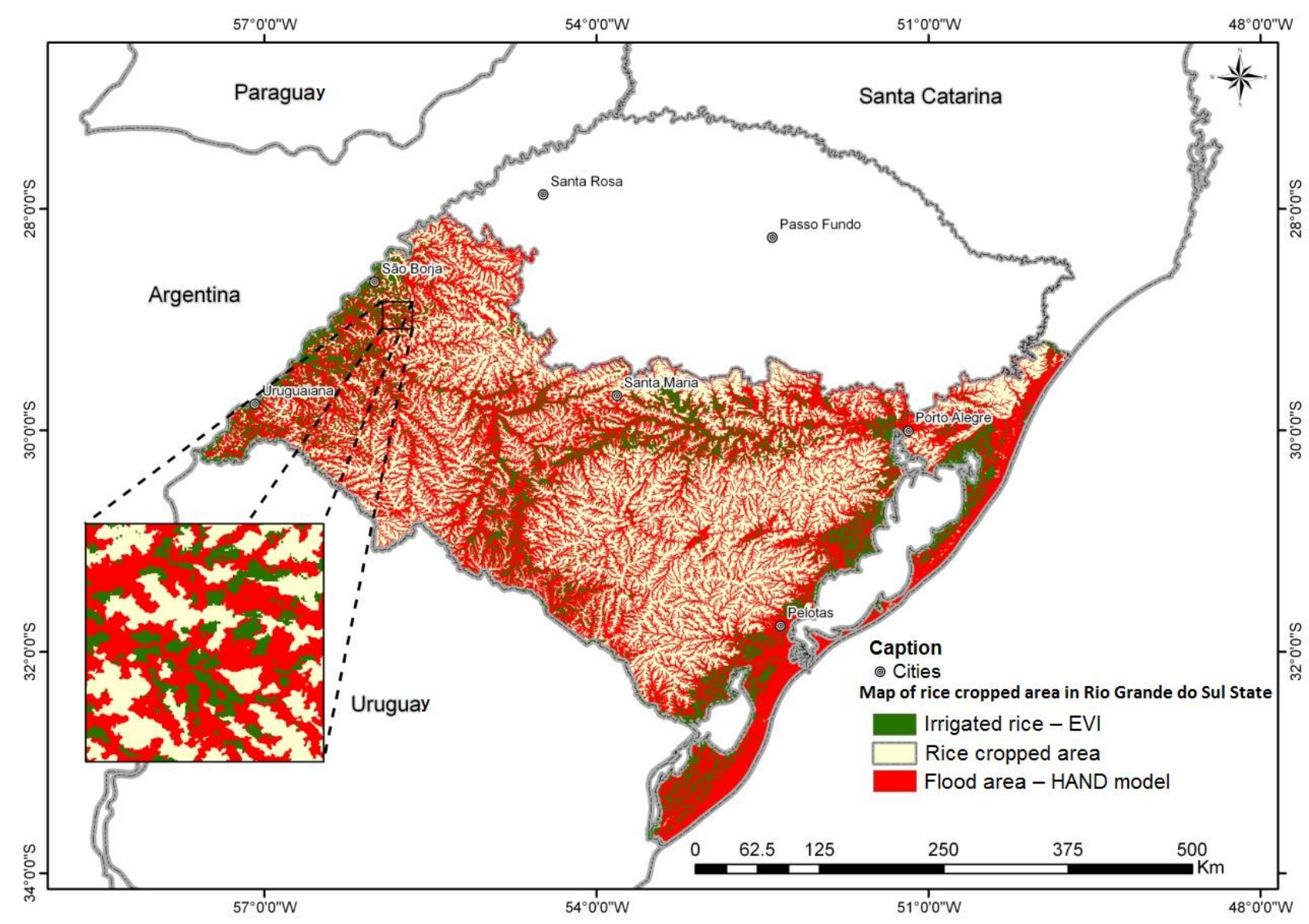

FIGURE 7. Map of irrigated rice area obtained by MODIS index - EVI in crop year 2011/2012.

Cross section of the ground (Figure 8) allows the view of floodplain areas of major rivers. These areas were used as a criterion for the flood mask construction. Also for separation of irrigated rice fields of spring and summer crops. Spectro-temporal criterion of MODIS images was used to classify areas. Some of them belonged to other summer and spring crops. They occup ied the highest areas. The ones classified as irrigated rice crops were restricted to floodplains. Delimitation of flood areas by HAND model was crucial for separation of conflict areas among rice crops and other crops with similar phenological crops, especially soybeans. D'ARCO (2007) said that determining areas for planting rice in Rio Grande do Sul State is necessary to separate rice from other crops. For the author, mappings that use only temporal criterion of MODIS images are not sufficient to separate irrigated rice from other summer crops, especially soybeans. The idea is coherent with results found in this study. 


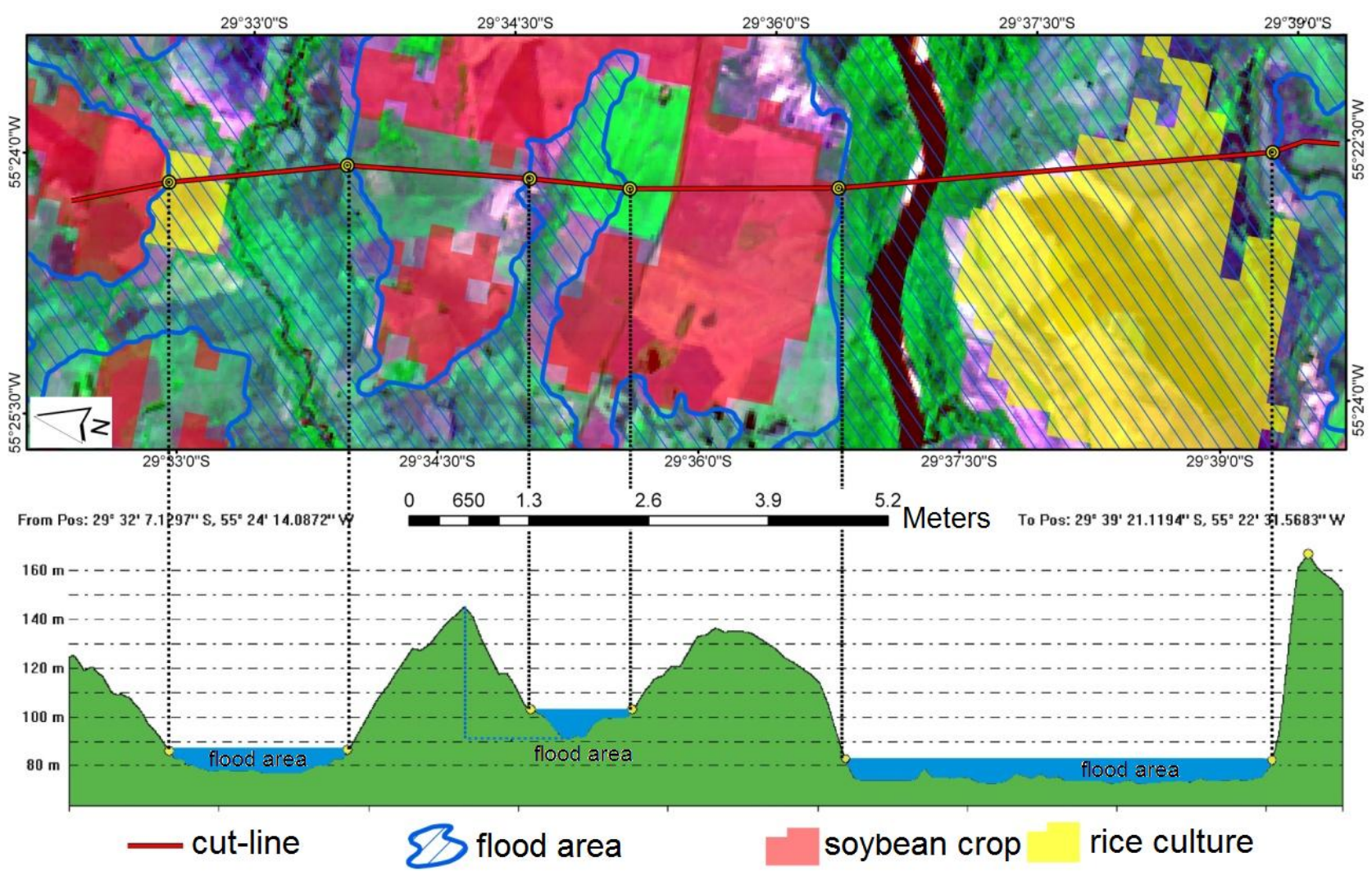

FIGURE 8. Cross land court illustrates lowland areas (flood). Altimetry data: SRTM. Image: Landsat 5 TM, composition RGB, 345. Date: 11/02/2011.

Delimitation of flood mask generated from HAND model is accurate and its implementation is fast. According to NOBRE et al. (2011), model quality depends on input data resolution. That is the quality of digital elevation model used. The smaller the pixel size, the more precise and reliable is the HAND model data.

There is another way to evaluate the efficiency of HAND model. Comparing the frequency distribution of pixels in rice fields to data quotas (heights) of SRTM or HAND model (Figure 9). For SRTM there are two peaks in the distribution of irrigated rice fields. The first peak corresponds to quotas close to sea level, near the coast. The second has quotas ranging from 60 to $100 \mathrm{~m}$, corresponding to the region further west in Rio Grande do Sul State. According to this distribution, topographic data in the form of quota is not sufficient criterion to define appropriate areas for rice cultivation in the State. Because of difference of quotas in traditional growing regions.

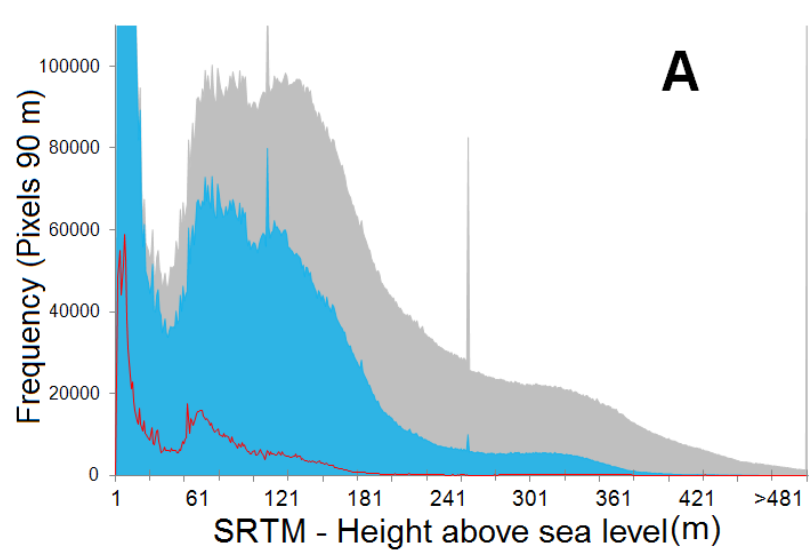

Rice cropped area

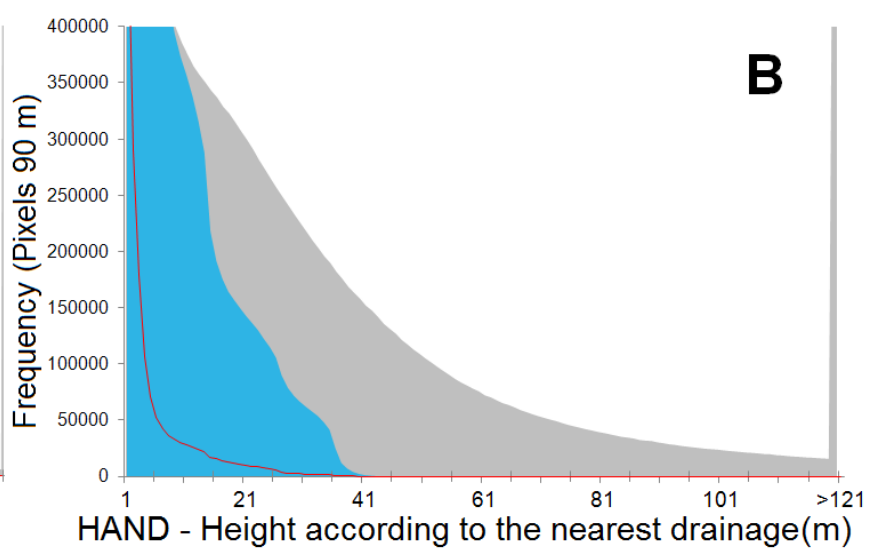

Flood area - Rice - EVI

FIGURE 9. Frequency distribution of heights related to SRTM (A) data quotas and frequency distribution of heights related to nearest drainage to HAND model (B). 
In pixel distribution obtained by means of HAND model, irrigated rice crops are more consistently identified, according to the region singularities. This is a consequence of the reference to local drainage network. There is a very strong connection between areas of irrigated rice and water bodies. This makes irrigated rice crops predominant in lowlands. According to SOSBAI (2012), Rio Grande do Sul State has large areas of irrigated rice crops through rammed earth cultivation system. Although there is water control, most crops irrigation are not completely scheduled. Flooding occurs from the highest levels. Water is driven by gravity. There is water slide through the rammed earth constructed with level differences of 5 to $10 \mathrm{~cm}$. In conclusion, water from flooded soil is very important for irrigated rice. It variates, however, according to weather conditions, attributes, soil type and crop management.

HAND model efficiency for identifying irrigated rice areas can be observed in table 1 . As it shows, about $84 \%$ of irrigated rice areas are located up to $9 \mathrm{~m}$ above the closest drainage. Heights above $30 \mathrm{~m}$ are not often used to establish irrigated rice tillage.

TABLE 1. Height compared to the nearest drainage for irrigated rice crops.

\begin{tabular}{cc}
\hline Height $(\mathbf{m})$-HAND & Rice-EVI $(\%)$ \\
\hline $0-9$ & 84.89 \\
$10-19$ & 11.01 \\
$20-29$ & 3.54 \\
$30-39$ & 0.54 \\
$>40$ & 0.02 \\
\hline
\end{tabular}

Analysis of a set of points collected in the field was compared to maps of MODIS-EVI classification in irrigated rice areas. As it shows, the processing made in this study is satisfactory (table 2). Global accuracy was $98.18 \%$ and Kappa Index (KI) was 0.92. For irrigated rice, the validation results and field reference matched validation results found in IBGE reference data. They were also higher than those found in previous studies about crops in the state.

TABLE 2. Confusion matrix for irrigated rice crops to Modis-EVI classification.

\begin{tabular}{|c|c|c|c|c|}
\hline \multicolumn{5}{|c|}{ Field Reference } \\
\hline & Rice & Non Rice & Total & Inclusion [\%] \\
\hline Theme Map & 321 & 30 & 351 & 8.55 \\
\hline Non Rice & 17 & 2228 & 2245 & 0.76 \\
\hline Total of field points & 338 & 2258 & 2596 & \\
\hline Omission [\%] & 5.03 & 1.33 & & \\
\hline
\end{tabular}

WEBER et al. (2007) estimated rice-cropped area in Rio Grande do Sul State for the 2005/2006 season by means of Landsat images. Through this, the authors assessed mapping accuracy using a set of GPS points, randomly spread throughout the cities within the study area. The authors considered satisfactory the KI value of 0.5665. GARCÍA et al. (2010) identified ricecropped areas in the provinces of Cundinamarca and Tolima in Colombia, an area of 4,519.01 $\mathrm{km}^{2}$, by means of NDVI data from Landsat 7 ETM+ and ASTER. The results were compared to a map generated by means of data from the field. They found KI values between 0.45 and 0.74 and EG higher than $72 \%$. Both studies used small dimension areas and satellites with small spatial resolution. They were less accurate than the ones in the present study were.

KLERING et al. (2011) used KI and EG to validate results of irrigated rice classification. They tested two mapping methodologies through MODIS sensor data, they obtained $96.6 \%$ EG and $0.55 \mathrm{KI}$. The studied area were rice crops in the extreme South of the State. The authors considered the results as good according to the table developed by LANDIS \& KOCH (1977). 
Other studies obtained spectro-temporal data of different crops. When compared to them, the quality of results in the present study is highlighted. ARAÚJO et al. (2011) mapped summer crops in Paraná State, with decennial compositions of NDVI images of SPOT Vegetation satellite in 2005/2006, 2006/2007 and 2007/2008 seasons. They compared the results to Landsat-5 TM images. The authors obtained KI values between 0.70 and 0.77 and EG values between $91 \%$ and $93 \%$. MERCANTE et al. (2012) found KI values over 0.63 and $79.05 \%$ EG. They compared Landsat5/TM spectro-temporal images of 2008/2009 season to results obtained by control points sampling. This was performed to detect areas sown with soybean throughout cities in the West of Paraná State.

While acquiring field points, were obtained only irrigated rice crops in fields compatible with MODIS sensor mapping scale. This means irrigated rice crops considered as small were omitted in validation analysis. This is an important factor for accuracy level. Crop areas considered as small had around 40 ha. This means areas with 6 to 7 pixels in 250 m resolution. Considering that the average size of irrigated rice crops is 114.57 ha (SOSBAI, 2012).

WARDLOW et al. (2006) used a similar procedure. They used field data to validate the study and obtained field samples with areas larger than 40.5 ha. Therefore, they guaranteed samples were detectable in MODIS sensor $250 \mathrm{~m}$ resolution.

Analysis of deletion and omission errors (table 2) showed that larger errors are concentrated on soybeans and corn crops. Spectrally irrigated rice has very different characteristics from other crops. In theory, irrigation system should easily distinguish irrigated rice from other crops by remote sensing techniques (GUMMA et al, 2011). According to D'ARCO et al. (2007), however, areas with similar cycle of spring and summer crops can be included in the mapping, such as soybeans and corn. Because of organic content thickness suspended in water depths.

\section{CONCLUSIONS}

The methodology proposed to develop a flood area using HAND model and it is efficient. It is used to separate floodplains, appropriate for rice cultivation, from higher areas that can be used for cultivation of other crops, such as soybeans.

There is a satisfactory accordance when validating the estimates of rice crops, through MODIS images, with official estimates from IBGE and field data. This shows that the methodology is promising. A few elements were essential to improve mapping quality of agricultural areas in Rio Grande do Sul State. Such as the filter application that reduces noise interference caused by clouds and smoothing the spectro-temporal curve of MODIS images.

Therefore, it is possible to generate and provide estimate data of irrigated rice crops area in Rio Grande do Sul State. This is possible by means of multitemporal and low spatial resolution data from MODIS sensor, combined with delimitation of flood areas, through the HAND model. This methodology is suitable for a regional scale and generates accurate estimates. It is easy and quick to implement and has low running cost.

\section{REFERENCES}

ARAÚJO, G.K.D,; ROCHA, J.V,; LAMPARELLI, R.A.C.; ROCHA, A.M. Mapping of summer crops in the state of Paraná, Brazil, through The 10-day spot vegetation NDVI composites.

Engenharia Agrícola, Jaboticabal, v.31, n.4, p.760-770, jul./ago. 2011.

BRASIL. Ministério da Agricultura, Pecuária e Abastecimento. Brasil em relevo. Brasília: Embrapa. Disponível em: <http://www.relevobr.cnpm.embrapa.br>. Acesso em: 15 dez. 2012.

BROWN, J.C.; KASTENS, J.H.; COUTINHO, A.C.; VICTORIA, D.C.; BISHOP, C.R. Classifying multiyear agricultural land use data from Mato Grosso using time-series MODIS vegetation index data. Remote Sensing of Environment, New York, v.130, p.39-50, 2013. 
D'ARCO, E. O uso de geotecnologias para estimativas da área plantada de arroz irrigado no estado do Rio Grande do Sul. 2007. 209 f. Tese (Doutorado) - Instituto Nacional de Pesquisas Espaciais, São José dos Campos, 2007.

Embrapa Informática Agropecuária. Banco de produtos MODIS na base estadual brasileira. Brasília: Embrapa, 2014. Disponível em:

<http://www.modis.cnptia.embrapa.br/geonetwork/srv/pt/main.home>. Acesso em 12 maio 2014.

EPIPHANIO, R.D.V.; FORMAGGIO, A.R.; RUDORFF, B.F.T.; MAEDA, E.E.; LUIZ, .J.B. Estimating soybean crop areas using spectral-temporal surfaces derived from MODIS images in Mato Grosso, Brazil. Pesquisa Agropecuária B rasileira, Brasília, v.45, p.72-80, 2010.

EXELIS VISUAL INFORMATION SOLUTIONS. Name of the manual. Boulder: Exelis Visual Information Solutions, 2010.

GARCÍA, J. S. A.; MARTÍNEZ, M. L. J. Satellite image based method for rice (Oryza sativa L.) crop identification. Agronomía Colombiana, Bogotá, v.28, n.2, p.281-290, 2010.

GUMMA, M. K.; NELSON, A.; THENKABAIL, P.S.; SINGH, A.N. Mapping rice areas of South Asia using MODIS multitemporal data. Journal of Applied Remote Sensing, Bellinghan, v.5 p.053547-053547-26, 2011.

HERMANCE, J.F.; JACOB, R.W.; BRADLEY, B.A; MUSTARD, J.F. Extracting Phenological Signals From Multiyear AVHRR NDVI Time Series: Framework for Applying High-Order Annual Splines With Roughness Damping. geoscience and remote sensing, New York, IEEE

Transactions on v.45, n.10, p.3264-3276. 2007.

HUETE, A.; JUS TICE, C.; LIU, H. Development of vegetation and soil indices for MODIS-EOS. Remote Sensing of Environment, New York, v. 49, p.224-234, 1994.

IBGE - INSTITUTO BRASILEIRO DE GEOGRAFIA E ESTATÍSTICA. Banco de dados agregados : sistema IBGE de recuperação automática - SIDRA. 2013. Disponível em: <http://www.sidra. ibge.gov.br>. Acesso em: 17 mar. 2014.

IBGE. Instituto Brasileiro de Geografia e Estatística - IBGE. Bases cartográficas: cartas. Rio de Janeiro: IBGE. Disponível em: < http://mapas.ibge.gov.br/pt/bases-e-referenciais/basescartograficas/cartas>. Acesso em: 14 dez. 2012.

INPE - INSTITUTO NACIONAL DE PESQUIS AS ESPACIAIS: TerraView 4.1.0. São José dos Campos: INPE, 2010. Disponível em: <www.dpi.inpe.br/terraview>. Acesso em: 13 set 2013.

JOHANN, J.A,; ROCHA, J.V.; DUFT, D.G.; LAMPARELLI, R.A.C. Estimativa de áreas com culturas de verão no Paraná, por meio de imagens multitemporais EVI/Modis. Pesquisa Agropecuá ria B rasileira, Brasilia, v.47, n.9, p.1295-1306, set. 2012.

KLERING, E.V.; FONTANA, D.C.; ALVES, R.; ROCHA, J.; BERLATO, M.A. Estimativa de área cultivada com arroz irrigado para o estado do rio grande do sul a partir de imagens Modis. Ciência e Natura, Santa Maria, v.35, n.2, p.126-135, dez. 2013.

KLERING, E.V.; WAGNER, A.P.L.; FONTANA, D.C.; BERLATO, M.A. Comparação entre dois métodos de estimativa de área cultivada com arroz irrigado no Rio Grande do Sul. In: SIMPÓSIO BRASILEIRO DE SENSORIAMENTO REMOTO, 15, 2011, Curitiba. Anais... São José dos Campos: INPE, 2011. p. 191-198.

LANDIS, J.R.; KOCH, G.G. The measurement of observer agreement for categorical data. Biometrics, Oxford, v.33, n.1, p.159-174, 1977.

MAPA - Ministério da Agricultura, Pecuária e Abastecimento. Agronegócio brasileiro: balança comercial. Disponível em: < http://www.agricultura.gov.br/internaciona1/indicadores-estatisticas/balancacomercial> Acesso em: 21 jun.2013. 
MERCANTE, E.; LIMA, L.E.P.; JUSTINA, D.D.; URIBE-OPAZO, M.A.; LAMPARELLI. Detection Of Soybean Planted Areas Through Orbital Images Based On Culture Spectral Dynamics. Engenharia Agrícola, Jaboticabal, v.32, n.5, p.920-931, set./out. 2012.

MUNARETO, J.D.; BEUTLER, A.N.; RAMÃO, C.J.; DIAS, N.P.; RAMOS, P.V.; POZZEBON, B.C.; ALBERTO, C.M.; HERNANDES, G.C. Prop riedades físicas do solo e produtividade de arroz irrigado por inundação no sistema plantio direto. Pesquisa Agropecuária B rasileira, Brasilia, v.45, n.12, p.1499-1506, dez. 2010.

NOBRE, A.D.; CUARTAS, L.A.; HODNETT, M.; RENNÓ, C.D.; RODRIGUES, G.O.; SILVEIRA, A.C.; WATERLOO, M.J.; SALESKA, S.R. Height Above the nearest Drainage, a hydrologically relevant new terrain model. Journal of Hydrology. Amsterdam, v. 404, p.13-29, 2011.

RENNÓ, C.D.; NOBRE, A.D.; CUARTAS, L.A.; SOARES, J.V.; HODNETT, M.G., TOMASELLA, J.; WATERLOO, M. HAND, a new terrain descriptor using SRTM DEM; Mapping terra-firme rainforest environments in Amazônia. Remote Sensing of Environme nt, New York, v.112, p.3469- 3481, 2008.

RISSO, J.; RIZZI, R.; RUDORFF, B.F.T.; ADAMI, M.; SHIMABUKURO, Y.E.; FORMAGGIO, A.R.; EPIPHANIO, R.D.V. Índices de vegetação Modis aplicados na discriminação de áreas de soja. Pesquisa Agropecuária Brasileira, Brasília , v.47, n.9, Sept. 2012.

SANTOS, J.S.; FONTANA, D.C.; SILVA, T.S.F,; RUDORFF, F.T. Identificação da dinâmica espaço-temporal para estimar área cultivada de soja a partir de imagens MODIS no Rio Grande do Sul. Revista Brasileira de Engenharia Agrícola e Ambiental, Campina Grande, v.18, n.1, p.5463, 2014.

SOSBAI - Sociedade Sul-Brasileira de Arroz Irrigado. Arroz irrigado- recomendações técnicas da pesquisa para do Sul do B rasil. Itajaí: Sociedade Sul- Brasileira de Arroz Irrigado. 2012. 179p. VICTORIA, D.C.; PAZ, A.R.; COUTINHO, A.C.; KASTENS, J.; BROWN, J.C. Cropland area estimates using Modis NDVI time series in the state of Mato Grosso, Brazil. Pesquisa Agropecuá ria B rasileira, Brasilia, v.47, n.9, p.1270-1278, 2012.

WARDLOW, B.D.; KASTENS, J.H.; EGBERT, S.L. Using USDA Crop Progress Data and MODIS Time-Series NDVI for Regional-Scale Evaluation of Greenup Onset Date.

Photogrammetric Engineering and Remote Sensing, Maryland, v.72, n. 11, p.1225- 1234, 2006.

WEBER, E.J.; WAGNER, A.P.L.; FONTANA, D.C.; DUCATI, J.R. Estimativa de área cultivada com arroz irrigado no Rio Grande do Sul na safra 2005/2006 através de imagens Landsat. In: SIMPÓSIO BRASILEIRO DE SENSORIAMENTO REMOTO, 13, 2007, Florianópolis. Anais... São José dos Campos: INPE, 2007. p. 465-472. 